(c) American Dairy Science Association, 2005.

\title{
Effect of Vacuum-Condensed or Ultrafiltered Milk on Pasteurized Process Cheese*
}

\author{
M. R. Acharya† and V. V. Mistry \\ MN-SD Dairy Foods Research Center, Dairy Science Department, \\ South Dakota State University, Brookings 57007
}

\begin{abstract}
Milk was concentrated by ultrafiltration (UF) or vacuum condensing $(\mathrm{CM})$ and milks with 2 levels of protein: 4.5\% (UF1 and CM1) and 6.0\% (UF2 and CM2) for concentrates and a control with $3.2 \%$ protein were used for manufacturing 6 replicates of Cheddar cheese. For manufacturing pasteurized process cheese, a 1:1 blend of shredded 18- and 30-wk Cheddar cheese, butter oil, and disodium phosphate (3\%) was heated and pasteurized at $74^{\circ} \mathrm{C}$ for $2 \mathrm{~min}$ with direct steam injection. The moisture content of the resulting process cheeses was 39.4 (control), 39.3 (UF1), 39.4 (UF2), 39.4 (CM1), and $40.2 \%$ (CM2). Fat and protein contents were influenced by level and method of concentration of cheese milk. Fat content was the highest in control (35.0\%) and the lowest in UF2 (31.6\%), whereas protein content was the lowest in control (19.6\%) and the highest in UF2 $(22.46 \%)$. Ash content increased with increase in level of concentration of cheese milk with no effect of method of concentration. Meltability of process cheeses decreased with increase in level of concentration and was higher in control than in the cheeses made with concentrated milk. Hardness was highest in UF cheeses $(8.45$ and $9.90 \mathrm{~kg}$ for UF1 and UF2) followed by CM cheeses (6.27 and $9.13 \mathrm{~kg}$, for CM1 and CM2) and controls (3.94 $\mathrm{kg})$. Apparent viscosity of molten cheese at $80^{\circ} \mathrm{C}$ was higher in the $6.0 \%$ protein treatments (1043 and 1208 $\mathrm{cp}, \mathrm{UF} 2$ and CM2) than in $4.5 \%$ protein treatments ( 855 and $867 \mathrm{cp}, \mathrm{UF} 1$ and CM1) and in control (557 cp). Free oil in process cheeses was influenced by both level and method of concentration with control (14.3\%) being the
\end{abstract}

Received April 16, 2005.

Accepted May 23, 2005.

Corresponding author: V. V. Mistry: e-mail: vikram.mistry@ sdstate.edu.

*Published with the approval of director of the South Dakota Agricultural Experiment Station as Publication Number 3483 of the Journal Series. This research was sponsored, in part, by the Minnesota-South Dakota Dairy Foods Research Center, Brookings, SD, and Midwest Dairy Association, St. Paul, MN.

$\dagger$ Current address: Wells Dairy, Inc., 1 1st Street S.W., Le Mars, IA 51031. lowest and CM2 (18.9\%) the highest. Overall flavor, body and texture, and acceptability were higher for process cheeses made with the concentrates compared with control. This study demonstrated that the application of concentrated milks (UF or CM) for Cheddar cheese making has an impact on pasteurized process cheese characteristics.

(Key words: ultrafiltration, condensing, process cheese)

Abbreviation key: $\mathbf{A M F}$ = anhydrous milk fat, $\mathbf{C M}=$ condensed milk, CM1 and CM2 = condensed milk cheese with 4.5 and $6.0 \%$ protein, respectively, UF1 and UF2 $=$ ultrafiltered milk cheese with 4.5 and $6.0 \%$ protein, respectively.

\section{INTRODUCTION}

A wide range of dairy ingredients (e.g., cheeses, milk protein concentrates, milk powders, whey, lactose, casein, caseinates, coprecipitates, and anhydrous milk fat) and nondairy ingredients of animal (e.g., ham, salami, smoked beef, seafood, fish, salmon, and prawns) or plant (e.g., spices, herbs, vegetables, and fruits) origin are used in the manufacture of process cheese (Chambre and Daurelles, 2000). In addition to these ingredients, emulsifiers play a vital role in determining characteristics of process cheese. Commonly used emulsifiers include citrates (disodium and trisodium) and phosphates (mono-, di-, tri-, and poly-) (Zehren and Nusbaum, 1992; Kosikowski and Mistry, 1997a; Chambre and Daurelles, 2000). Properties of cheese such as meltability and sliceability can be adjusted by use of these emulsifiers in isolation or combination (Gupta et al., 1984).

The emulsifiers function by improving the emulsification ability of casein. Various types of emulsifiers may be used, including different combinations of citrates and phosphates such as trisodium citrate, disodium and trisodium phosphates (orthophosphates), polyphosphates, and others. The selection of emulsifiers depends on properties desired in the final cheese. For example, disodium phosphate, which is widely used, provides cheese with optimum firmness and melting 
quality. Trisodium citrate provides firmness and is therefore desirable for production of slices but not spreads. Polyphosphates, on the other hand, give firmness and tart flavor. Pyrophosphates heavily restrict melting and have application in meat products where melting out of cheese is not desired. The amount of emulsifier used will also influence properties. Current regulations in the United States allow up to $3 \%$ addition.

The selection of base cheese is also critical in the manufacture of process cheese. The base cheese serves to provide body and texture as well as flavor. Body and texture is generally achieved with young cheese, and flavor with aged cheese. Therefore, a blend of young and aged cheese is required (Berger et al., 1989; Zehren and Nusbaum, 1992; Kosikowski and Mistry, 1997a). Excessive amounts of young cheese will lead to poor flavor, whereas excessive amounts of aged cheese will produce poor body. The age of cheese is an important factor because it determines the extent of proteolysis and flavor. For optimum functional characteristics, such as melting, the amount and structural characteristics of the proteins are critical. As a cheese ages, proteins hydrolyze into smaller proteins and peptides and there is reduced interaction among these shorter proteins. Consequently, process cheese manufactured from such aged cheese is less elastic and may be crumbly (Shimp, 1985) and have excessive meltability (Thomas, 1970). It is important therefore for process cheese manufacturers to be able to select a base cheese with the desired degree of proteolysis and importantly, according to commercial manufacturers, to be able to control proteolysis.

In an earlier publication, the impact of vacuum condensing or ultrafiltering milk before Cheddar cheese making was reported (Acharya and Mistry, 2004). It was concluded that these 2 concentration techniques resulted in Cheddar cheeses of distinctly different quality compared with controls. Although both methods have distinct features, the selection of the method (vacuum condensing or ultrafiltration) would depend, in part, upon the intended use of the cheese, such as for table cheese or for further processing. It has been well established that characteristics of process cheese depend on the characteristics of base cheese (Zehren and Nusbaum, 1992; Kosikowski and Mistry, 1997a). The objective of this study was to compare the effect of ultrafiltration and vacuum condensing on composition, sensory, and some functional properties of pasteurized process cheeses.

\section{MATERIALS AND METHODS}

\section{Process Cheese Making}

Young (18 wk) and aged (30 wk) Cheddar cheeses were manufactured as described previously (Acharya and Mistry, 2004): a control cheese made from milk with $3.2 \%$ protein, and cheeses made with ultrafiltered milk with $4.5 \%$ (UF1) and $6.0 \%$ protein (UF2), and vacuum-condensed milk with $4.5 \%$ (CM1) and $6.0 \%$ protein (CM2).

Formulation of pasteurized process cheese was done using young and aged Cheddar cheese, anhydrous milk fat (AMF), and 3\% disodium phosphate to obtain 38.5\% moisture in the final product (Table 1). Batch size was $16 \mathrm{~kg}$. A Damrow single auger, direct steam injection cheese cooker (model no. 84-062, Damrow, Fond du Lac, WI) was used for process cheese manufacture. Steam injection was done at $4.2 \mathrm{~kg} / \mathrm{cm}^{2}$, temperature of pasteurization was $74^{\circ} \mathrm{C}$, and holding time was $2 \mathrm{~min}$. At the end of the holding period, the process cheese was packaged in half-gallon plastic containers, inverted, and stored at $4^{\circ} \mathrm{C}$ until analyzed.

\section{Composition Analysis}

Representative samples of process cheese were obtained from one of the containers by drawing approximately $100 \mathrm{~g}$ from the container after $48 \mathrm{~h}$ of cold storage, and then were shredded and analyzed for chemical composition. Moisture was determined using an Ohaus MB200 moisture balance (Ohaus Corp., Florham Park, NJ; Crosser and Mistry, 1991). Total nitrogen was determined by the Kjeldahl method (991.20; AOAC, 2000). Protein was calculated by multiplying total $\mathrm{N}$ by a factor of 6.38. Fat was determined by the Mojonnier method (995.19; AOAC, 2000) and ash content by heating a 0.5 -g sample in the oven at $100^{\circ} \mathrm{C}$ for 3 to $4 \mathrm{~h}$, followed by heating at $200^{\circ} \mathrm{C}$ for $2 \mathrm{~h}$ and $550^{\circ} \mathrm{C}$ overnight in a muffle furnace (935.42; AOAC, 2000). A Corning $\mathrm{pH}$ meter (model 320, Corning Inc., Corning, NY) was used to measure $\mathrm{pH}$.

\section{Meltability}

The cheese samples were analyzed for meltability using the Schreiber test (Kosikowski and Mistry, 1997b). Cheese discs (39 $\mathrm{mm}$ diameter and $5 \mathrm{~mm}$ thickness) were placed in the center of glass Petri plates and heated in a hot air oven at $232^{\circ} \mathrm{C}$ for $5 \mathrm{~min}$. Diameter of melted cheese circles was measured after cooling for $30 \mathrm{~min}$. Average values of 5 readings of diameter at different places on the melted disc were recorded in centimeters.

\section{Apparent Viscosity}

Apparent viscosity was determined using a Rapid Visco Analyzer (model RVA-4, Newport Scientific Pvt. Ltd., Warriewood, Australia) (Metzger and Leman, 
Table 1. Pasteurized process cheese formulation.

\begin{tabular}{lrrrrr}
\hline & \multicolumn{5}{c}{ Treatment $^{1}$} \\
\cline { 2 - 6 } Ingredient (kg) & $\mathrm{C}$ & $\mathrm{UF} 1$ & $\mathrm{UF} 2$ & $\mathrm{CM} 1$ & CM2 \\
\hline 18-wk Cheddar cheese & 6.29 & 6.45 & 6.86 & 6.47 & 6.77 \\
30-wk Cheddar cheese & 6.29 & 6.45 & 6.86 & 6.47 & 6.77 \\
Anhydrous milk fat & 1.68 & 1.36 & 0.53 & 1.32 & 0.72 \\
Disodium phosphate & 0.48 & 0.48 & 0.48 & 0.48 & 0.48 \\
Condensate & 1.16 & 1.16 & 1.16 & 1.16 & 1.16 \\
Total & 15.89 & 15.89 & 15.89 & 15.89 & 15.89 \\
\hline
\end{tabular}

${ }^{1}$ Treatment: $\mathrm{C}=$ control; UF1 $=4.5 \%$ protein ultrafiltered milk; UF2 $=6.0 \%$ protein ultrafiltered milk; $\mathrm{CM} 1=4.5 \%$ protein condensed milk; CM2 $=6.0 \%$ protein condensed milk.

2001) as follows. Before testing, the samples were held at $2^{\circ} \mathrm{C}$ overnight. Samples were then shredded and stored at $2^{\circ} \mathrm{C}$ for another $30 \mathrm{~min}$. Fourteen grams of shredded process cheese and $1 \mathrm{~g}$ of propylene glycol were weighed in an aluminum canister and placed in the analyzer. The heating/cooling core was tempered to $25^{\circ} \mathrm{C}$ and programmed to raise the temperature of the cheese to $80^{\circ} \mathrm{C}$, hold for $3 \mathrm{~min}$, and cool to $25^{\circ} \mathrm{C}$. The agitator was programmed to start after $3 \mathrm{~min}$ and operated at $300 \mathrm{rpm}$. The analyzer was interfaced with a computer using Thermocline for Windows software (Version 2.2, Newport Scientific Pvt. Ltd.) and apparent viscosity readings were recorded by the computer every $4 \mathrm{~s}$. The lowest apparent viscosity (cp) observed during the 3-min holding period was recorded and used for comparison.

\section{Hardness}

A Sintech texture instrument (model 2/D, MTS Sintech Inc., Research Triangle Park, NC) with a crosshead speed of $50 \mathrm{~mm} / \mathrm{min}$ and a $45.4-\mathrm{kg}$ load cell was used for texture profile analysis on $2 \mathrm{~cm} \times 2 \mathrm{~cm}$ cylindrical samples of process cheese. A 2-bite test to $80 \%$ compression was used (van Vliet, 1990). Hardness was calculated using Test-Works software version 2.1 (TestWorks Software, Research Triangle Park, NC) and recorded in kilograms.

\section{Free Oil}

The free oil content was determined by a rapid quantitative test described by Kindstedt and Rippe (1990) using $18 \mathrm{~g}$ of ground cheese. Free oil content was noted as free oil (measured fat column $\div 2$ ) and expressed as percentage.

\section{Sensory Evaluation}

Samples were evaluated for flavor and body and texture characteristics by a panel of 5 experienced judges. The treatments were labeled using a random 3-digit number and presented to judges in identical containers to avoid bias. The scores for flavor, body, and texture characteristics were recorded and compared.

\section{Statistical Analyses}

The data were analyzed using factorial randomized block design with method (control, UF, and CM) and level of concentration $(3.2,4.5$, and $6.0 \%$ protein) as factors. Means were compared using Fisher's Least Significant Difference (LSD) procedure. Sensory data were analyzed using completely randomized design. The GLM procedure of SAS (SAS Institute, 1995) was used to analyze the data. A 95\% level of significance was used for all analyses. Six replicates of cheese making were conducted.

\section{RESULTS AND DISCUSSION}

\section{Composition of Cheese}

Effects of milk concentration methods, concentration levels, and interactions are shown in Table 2. Cheeses from CM2 had a higher $(P \leq 0.05)$ moisture content

Table 2. Analysis of variance (ANOVA) for process cheese composition and properties.

\begin{tabular}{lcrc}
\hline & \multicolumn{3}{c}{$F$ value for source of variation } \\
\cline { 2 - 4 } Property & \multicolumn{1}{c}{$\mathrm{C}^{1}$} & \multicolumn{1}{c}{$\mathrm{L}^{2}$} & $\mathrm{C} \times \mathrm{L}$ \\
\hline Moisture & $3.99^{*}$ & $8.25^{*}$ & $6.08^{*}$ \\
Fat & $145.56^{*}$ & $453.76^{*}$ & $12.26^{*}$ \\
Protein & $143.39^{*}$ & $144.57^{*}$ & $0.29^{\mathrm{NS}}$ \\
Ash & $65.70^{*}$ & $81.61^{*}$ & $1.44^{\mathrm{NS}}$ \\
$\mathrm{pH}$ & $2.64^{\mathrm{NS}}$ & $5.34^{*}$ & $0.62^{\mathrm{NS}}$ \\
Meltability & $9.50^{*}$ & $5.48^{*}$ & $0.07^{\mathrm{NS}}$ \\
Hardness & $18.38^{*}$ & $9.27^{*}$ & $0.99^{\mathrm{NS}}$ \\
Free oil & $89.60^{*}$ & $116.90^{*}$ & $5.99^{*}$ \\
Apparent viscosity & $21.33^{*}$ & $18.60^{*}$ & $1.55^{\mathrm{NS}}$ \\
\hline
\end{tabular}

${ }^{1} \mathrm{C}=$ Method of concentration; there were 3 methods of concentration; control (none), ultrafiltration, and vacuum condensing.

${ }^{2} \mathrm{~L}=$ Level of concentration; there were 3 levels of concentration; $3.2,4.5$, and $6 \%$ protein.

*Significant $(P \leq 0.05) ; \mathrm{NS}=$ nonsignificant $(P>0.05)$. 
Table 3. Composition of pasteurized process cheese. ${ }^{1}$

\begin{tabular}{|c|c|c|c|c|c|c|}
\hline \multirow[b]{2}{*}{ Parameter } & \multicolumn{5}{|c|}{ Treatment $^{2}$} & \multirow[b]{2}{*}{ SEM } \\
\hline & $\mathrm{C}$ & UF1 & UF2 & CM1 & CM2 & \\
\hline Moisture, \% & $39.4^{\mathrm{b}}$ & $39.3^{\mathrm{b}}$ & $39.4^{\mathrm{b}}$ & $39.3^{b}$ & $40.2^{\mathrm{a}}$ & 0.40 \\
\hline Fat, \% & $35.0^{\mathrm{a}}$ & $33.7^{\mathrm{c}}$ & $31.6^{\mathrm{d}}$ & $34.6^{\mathrm{b}}$ & $31.7^{\mathrm{d}}$ & 0.28 \\
\hline Protein, \% & 19.6 & 21.2 & 22.6 & 20.1 & 21.5 & 0.27 \\
\hline Ash, \% & 4.7 & 5.0 & 5.3 & 5.0 & 5.4 & 0.10 \\
\hline $\mathrm{pH}$ & 6.0 & 6.0 & 6.1 & 6.1 & 6.2 & 0.14 \\
\hline
\end{tabular}

(40.2\%) than those from the other 4 treatments (39.3 to $39.4 \%$; Table 3 ). This may be explained by the incorporation of additional condensate during prolonged heating needed (approximately 2 to 3 additional minutes) to obtain a completely melted, homogeneous blend during process cheese making.

Fat content was different with significant $(P \leq 0.05)$ effects of both level and method of concentration and their interaction (Table 3). Cheeses from UF1 had lower fat content than CM1 cheeses, whereas UF2 and CM2 cheeses had the lowest fat content. The fat content decreased with an increase in the level of concentration perhaps because of differences in moisture content of Cheddar cheeses (Acharya and Mistry, 2004). Cheddar cheeses from CM1 had higher moisture content compared with UF1 cheeses and, hence, required more AMF to obtain the target moisture of 39\%, resulting in higher fat content. Control Cheddar cheeses had the highest moisture content, thus requiring the largest quantities of AMF to compensate for condensate addition.

Protein content was influenced $(P \leq 0.05)$ by both method and level of concentration; UF cheeses had the highest level of protein followed by CM and control cheeses, and protein content in cheese increased as the level of concentration of cheese milk increased (Table 3 ). This could be attributed to similar trends in protein contents of base Cheddar cheeses used to manufacture process cheese (Table 4). Kosikowski et al. (1985) reported similar effects in Cheddar cheese made from whole milk supplemented with UF milk. Jensen et al. (1987) have discussed many similar reports in their review of cheese composition made from UF milk.

There were significant $(P \leq 0.05)$ differences in the ash content of cheeses. Only the effect of level of concentration was significant $(P \leq 0.05)$; there was no effect of method of concentration. Ash content increased as the level of concentration of cheese milks increased. Base Cheddar cheeses had similar effect of level of concentration on ash content. Kosikowski et al. (1985) reported an increase in the ash content of Cheddar cheeses with an increase in the level of concentration of cheese milk. The $\mathrm{pH}$ of process cheeses was significantly $(P \leq 0.05)$ affected by level of concentration only. There were no differences between UF and CM. This could be explained by similar trends in $\mathrm{pH}$ of base Cheddar cheese (Acharya and Mistry, 2004).

\section{Meltability}

Meltability of process cheeses ranged from 74.8 (control) to $62.2 \mathrm{~mm}$ (CM2). Only level of concentration had significant $(P \leq 0.05)$ effect on meltability (Table 5$)$. There were no differences between meltability of UF $(67.6 \mathrm{~mm})$ and $\mathrm{CM}(64.7 \mathrm{~mm})$ cheeses, but control cheeses exhibited significantly higher meltability (74.8 $\mathrm{mm})$ than $\mathrm{CM}$ cheeses $(P \leq 0.05)$. Overall, there was a significant $(P \leq 0.05)$ increase in meltability of process cheeses from concentrates when compared with respective base Cheddar cheeses at 18 or 30 wk (Table 4 and $5)$. However, in the case of the control, the meltability values for process cheese $(74.8 \mathrm{~mm})$ were between that of respective base Cheddar cheeses at $18(70.2 \mathrm{~mm})$ and $30 \mathrm{wk}(77.2 \mathrm{~mm})$ of ripening. Meltability of process cheeses is dependent on the meltability of the base Cheddar cheeses and the type of emulsifier used (Kosikowski and Mistry, 1997a). An increase in meltability can be directly correlated with the extent of proteolysis in base cheese that results in breakdown of the casein matrix, release of calcium, and increased hydration (Lawrence, 1987). Oommen et al. (2000) observed an increase in meltability of Cheddar cheese with ripening in both control and UF Cheddar cheeses. Aizawa and Yoneda (1990) reported reduction in meltability of process cheeses by 1) reducing ratio of fat:protein, 2) using calcium salt, and 3) extending cooking time or using higher temperature holding. Lower fat:protein ratio in UF base Cheddar cheeses, higher calcium content in base Cheddar cheeses from concentrates, and higher cooking temperature and longer holding time (possible denaturation of whey proteins) for CM2 process cheeses 
Table 4. Composition of Cheddar cheese at $1 \mathrm{wk}$ of age and meltability of aged cheese. ${ }^{1,2}$

\begin{tabular}{|c|c|c|c|c|c|c|}
\hline & \multicolumn{5}{|c|}{ Treatment $^{3}$} & \multirow[b]{2}{*}{ SEM } \\
\hline & $\mathrm{C}$ & UF1 & UF2 & CM1 & CM2 & \\
\hline Moisture, \% & 39.2 & 37.8 & 36.5 & 38.6 & 36.7 & 0.75 \\
\hline Protein, \% & 24.9 & 25.6 & 26.4 & 24.7 & 25.4 & 0.47 \\
\hline Fat, \% & 32.1 & 32.1 & 32.4 & 31.6 & 31.5 & 0.61 \\
\hline Salt, \% & $1.4^{\mathrm{b}}$ & $1.4^{\mathrm{b}}$ & $1.4^{\mathrm{b}}$ & $1.5^{\mathrm{b}}$ & $1.8^{\mathrm{a}}$ & 0.17 \\
\hline Calcium, \% & 0.68 & 0.75 & 0.80 & 0.71 & 0.77 & 0.05 \\
\hline $\mathrm{pH}$ & 5.1 & 5.1 & 5.1 & 5.0 & 5.1 & 0.06 \\
\hline \multicolumn{7}{|l|}{ Meltability, mm } \\
\hline 18-wk-old cheese & $70.2^{\mathrm{a}}$ & $66.5^{\mathrm{b}}$ & $58.8^{\mathrm{c}}$ & $56.7^{\mathrm{c}}$ & $52.0^{\mathrm{d}}$ & 2.8 \\
\hline 30-wk-old cheese & $77.2^{\mathrm{a}}$ & $67.6^{\mathrm{b}}$ & $61.5^{\mathrm{c}}$ & $57.7^{\mathrm{cd}}$ & $54.1^{\mathrm{d}}$ & 4.8 \\
\hline
\end{tabular}

could be important contributing factors for differences observed in meltability.

\section{Hardness}

Hardness was significantly $(P \leq 0.05)$ influenced by both level and method of concentration (Table 5). Hardness increased from 3.9 (control) to 6.3 (CM1) and 8.5 (UF1) to 9.1 (CM2) and $9.9 \mathrm{~kg}$ (UF2) with increase in level of concentration. This coincides with a reduction in the extent of breakdown of caseins in base Cheddar cheeses upon increase in level of concentration; using SDS-PAGE, Acharya and Mistry (2004) demonstrated retarded proteolysis with an increase in level of concentration. The breakdown of $\alpha_{\mathrm{s} 1}$-casein and $\alpha_{\mathrm{s} 1}$-I-casein fractions was highest in the control and decreased with increase in protein content of cheese milk, with UF2 being the lowest. There was no significant degradation of $\beta$-casein. Overall increase in proteolytic products was the highest in control, and it decreased with increase in protein content of cheese milk. The higher proportion of proteins in DM in UF cheeses could be another factor contributing toward hardness $(32.3 \%$, control; 34.9\%, UF1; and 37.3\%, UF2). Oommen et al. (2000) reported increased hardness of Cheddar cheeses that were manufactured from milk whose protein concentration was increased by supplementation with UF retentates. Hardness decreased with increase in proteolysis. Green et al. (1981) suggested that lower moisture content, lower proteolysis, coarser and stronger protein networks, and reduced ability of fat and protein phase to move in relation to each other tend to increase hardness. It is interesting to note that the CM2 process cheeses had higher moisture contents but they were harder than the lower moisture cheeses. There was no significant correlation $(\mathrm{r}=0.5)$ between hardness and meltability.

\section{Free Oil}

There were significant $(P \leq 0.05)$ differences in the free oil content of the cheeses. Control had the lowest amount of free oil (14.3\%) and it increased with level of concentration (Table 5). Effect of both method and

Table 5. Functional properties of pasteurized process cheese. ${ }^{1}$

\begin{tabular}{lcccccr}
\hline & \multicolumn{5}{c}{ Treatment $^{2}$} \\
\cline { 2 - 5 } Parameter & $\mathrm{C}$ & UF1 & UF2 & CM1 & CM2 & SEM \\
\hline Meltability, mm & 74.8 & 69.5 & 65.6 & 67.1 & 62.2 & 4.64 \\
Hardness, kg & 3.9 & 8.5 & 9.9 & 6.3 & 9.1 & 1.73 \\
Free oil, \% & $14.3^{\mathrm{d}}$ & $15.1^{\mathrm{c}}$ & $16.8^{\mathrm{b}}$ & $16.2^{\mathrm{b}}$ & $18.9^{\mathrm{a}}$ & 0.50 \\
Apparent viscosity, cp & 557 & 855 & 1043 & 867 & 1208 & 150.0 \\
\hline a,b,c,d Means in the same row without common superscripts are significantly different $(P \leq 0.05)$. Means \\
with no superscripts do not have significant interaction between method and level of concentration. \\
11Mean of 6 replicates. \\
2Treatment: C = control; UF1 = 4.5\% protein ultrafiltered milk; UF2 = 6.0\% protein ultrafiltered milk; \\
CM1 = 4.5\% protein condensed milk; CM2 = 6.0\% protein condensed milk.
\end{tabular}


Table 6. Sensory scores of pasteurized process cheese. ${ }^{1}$

\begin{tabular}{lllllll}
\hline & \multicolumn{5}{c}{ Treatment $^{2}$} \\
\cline { 2 - 5 } Parameter & $\mathrm{C}$ & $\mathrm{UF} 1$ & $\mathrm{UF} 2$ & CM1 & CM2 & SEM \\
\hline Flavor intensity $^{3}$ & $7.2^{\mathrm{a}}$ & $7.5^{\mathrm{a}}$ & $7.5^{\mathrm{a}}$ & $7.7^{\mathrm{a}}$ & $7.4^{\mathrm{a}}$ & 0.52 \\
Overall flavor $^{4}$ & $6.9^{\mathrm{b}}$ & $7.8^{\mathrm{a}}$ & $8.0^{\mathrm{a}}$ & $7.6^{\mathrm{a}}$ & $7.7^{\mathrm{a}}$ & 0.59 \\
Firmness $^{3}$ & $4.1^{\mathrm{c}}$ & $5.5^{\mathrm{ab}}$ & $6.2^{\mathrm{a}}$ & $5.0^{\mathrm{b}}$ & $5.7^{\mathrm{ab}}$ & 0.74 \\
Pastiness $^{3}$ & $3.2^{\mathrm{a}}$ & $1.3^{\mathrm{b}}$ & $1.1^{\mathrm{b}}$ & $1.9^{\mathrm{b}}$ & $2.0^{\mathrm{b}}$ & 0.68 \\
Mealiness $^{3}$ & $2.2^{\mathrm{a}}$ & $1.7^{\mathrm{ab}}$ & $2.0^{\mathrm{ab}}$ & $1.5^{\mathrm{b}}$ & $1.7^{\mathrm{ab}}$ & 0.50 \\
Crumbliness $^{3}$ & $1.7^{\mathrm{a}}$ & $1.9^{\mathrm{a}}$ & $1.9^{\mathrm{a}}$ & $1.5^{\mathrm{a}}$ & $1.6^{\mathrm{a}}$ & 0.40 \\
Overall body and texture $^{4}$ & $6.6^{\mathrm{b}}$ & $7.8^{\mathrm{a}}$ & $7.9^{\mathrm{a}}$ & $7.6^{\mathrm{a}}$ & $7.5^{\mathrm{a}}$ & 0.42 \\
Appearance $^{\mathrm{a}}$ & $8.3^{\mathrm{b}}$ & $9.0^{\mathrm{a}}$ & $9.1^{\mathrm{a}}$ & $8.5^{\mathrm{ab}}$ & $8.8^{\mathrm{ab}}$ & 0.50 \\
Overall acceptability $^{4}$ & $6.6^{\mathrm{c}}$ & $8.0^{\mathrm{ab}}$ & $8.3^{\mathrm{a}}$ & $7.5^{\mathrm{b}}$ & $8.0^{\mathrm{ab}}$ & 0.56 \\
\hline
\end{tabular}

a,b,c Means in the same row without common superscripts are significantly $(P \leq 0.05)$ different.

${ }^{1}$ Mean of 6 replicates.

${ }^{2}$ Treatment: $\mathrm{C}=$ control; UF1 $=4.5 \%$ protein ultrafiltered milk; UF2 $=6.0 \%$ protein ultrafiltered milk; $\mathrm{CM} 1=4.5 \%$ protein condensed milk; $\mathrm{CM} 2=6.0 \%$ protein condensed milk.

${ }^{3}$ Measured on a scale from 1 (low intensity) to 10 (high intensity).

${ }^{4}$ Measured on a scale from 1 (unacceptable) to 10 (excellent).

level of concentration were significant $(P \leq 0.05)$. Condensed milk cheeses had higher free oil than the corresponding UF cheeses. In spite of differences being statistically significant, from an application point of view, a variation from $14.3 \%$ (control) to $18.9 \%$ (CM2) may not be that important in influencing the end use of such process cheeses. Free oil content is an indication of the degree of emulsification of fat in cheese (Metzger and Mistry, 1994; Tunick, 1994). The higher proportion of protein in DM in UF cheeses compared with CM cheeses may entrap more fat resulting in lower free oil. Oommen et al. (2000) also observed a decrease in free oil content of Cheddar cheeses with the use of ultrafiltration. However, control had lower free oil content than concentrates in the present study. It was suggested by Oommen et al. (2000) that the components released during proteolysis probably aided in emulsification of fat, resulting in lower free oil with increased proteolysis. Additional work may be needed to understand the mechanism involved in this phenomenon.

\section{Apparent Viscosity}

Apparent viscosity was significantly $(P \leq 0.05)$ influenced by level of concentration, but there was no effect of method of concentration (Table 5). Control had the lowest apparent viscosity followed by cheeses from 4.5 and $6.0 \%$ protein milk. Interestingly, the increase in apparent viscosity was in proportion to the increase in level of concentration from control to concentrates, approximately $1.5 \times$ and $2.0 \times$, respectively. Entrapment of free water by denatured whey proteins (Sood and Kosikowski, 1979) and limited proteolysis in cheeses from concentrates are some of the probable reasons for differences in apparent viscosity. Aizawa and Yoneda (1990) reported an increase in apparent viscosity of process cheese by 1) reducing ratio of fat:protein, 2) using calcium salt, and 3) extending cooking time or using higher temperature holding. In the present study, lower fat:protein ratio in base Cheddar cheeses from concentrates (control: 1.29, UF1: 1.25, UF2: 1.23, CM1: 1.28, CM2: 1.24) and higher calcium content in both UF and CM base Cheddar cheeses, and extended cooking time at higher temperature in CM2 could be the reason for higher apparent viscosity values in concentrates when compared with control. Effect of these factors on functional properties of process cheese was further confirmed by the fact that apparent viscosity had significant negative correlation with meltability $(\mathrm{r}=$ $-0.68)$ and positive correlation with hardness $(r=0.78)$.

\section{Sensory Evaluation}

Significant differences $(P \leq 0.05)$ were observed in sensory scores of different treatments (Table 6). Firmness was perceived to be lowest in the control, and highest in UF2 process cheeses. Control samples were reported to be pasty compared with process cheeses from concentrates. Overall body and texture scores were higher for process cheese from concentrates than those from the control. Process cheese from concentrates obtained higher overall acceptability scores than control. There were no differences in the flavor intensity and crumbliness of the process cheese from different treatments. There was no effect of level of concentration on any of the sensory parameters. There were no differences between UF and CM process cheeses for any of the sensory parameters. From the results of sensory evaluation, it seems that use of concentration improves sensory properties of process cheese by reducing bitterness, pastiness, and mealiness regardless of level or 
method of concentration within the range used in this study.

\section{CONCLUSIONS}

Concentrated milks when used for manufacturing base Cheddar cheese have a direct impact on pasteurized process cheese characteristics. Although the meltability of process cheeses was higher than the respective base Cheddar cheeses, process cheeses from UF and CM concentrates had limited meltability compared with the control. By formulation to similar moisture, the effect of moisture is also eliminated in process cheeses. Hence, proteolysis and calcium content seem to be important variables influencing meltability. Milk concentration by vacuum condensing or ultrafiltration is an additional method for manipulating the characteristics of process cheese.

\section{REFERENCES}

Acharya, M. R., and V. V. Mistry. 2004. Comparison of effect of vacuum condensed and ultrafiltered milk on Cheddar cheese making. J. Dairy Sci. 87:4004-4012.

Aizawa, S., and Y. Yoneda. 1990. Preparation of melt-resistant Process cheese. Brief Commun. XXIII Int. Dairy Congr., Montreal, Canada. Vol. II. International Dairy Federation, Brussels, Belgium.

AOAC. 2000. Official Methods of Analysis. Association of Official Analytical Chemists, International, Gaithersburg, MD.

Berger, W., H. Klostermeyer, K. Merkenich, and G. Uhlmann. 1989. Processed Cheese Manufacture. BK Ladenburg, Ladenburg, Germany.

Chambre, M., and J. Daurelles. 2000. Processed cheese. Pages 641657 in Cheesemaking. From Science to Quality Assurance. 2nd ed. A. Eck and J. Gillis, ed. Intercept Ltd., Hampshire, UK.

Crosser, A. E., and V. V. Mistry. 1991. Use of a moisture balance to determine moisture in cheese. J. Dairy Sci. 74(Suppl. 1):126. (Abstr.)

Green, M. L., F. A. Glover, E. M. W. Scurlock, R. J. Marshall, and D. A. Hatfield. 1981. The effect of use of milk concentrated by ultrafiltration on the manufacture and ripening of Cheddar cheese. J. Dairy Res. 48:333-341.

Gupta, S. K., C. Karahadian, and R. C. Lindsay. 1984. Effect of emulsifier salts on textural and flavor properties of processed cheeses. J. Dairy Sci. 67:764-778.

Jensen, L. A., M. E. Johnson, and N. F. Olson. 1987. Composition and properties of cheeses from milk concentrated by ultrafiltration and reverse osmosis-A review of literature. Cult. Dairy Prod. J. 22:6-14.

Kindstedt, P. S., and J. K. Rippe. 1990. Rapid quantitative test for free oil (oiling off) in melted Mozzarella cheese. J. Dairy Sci. 73:867-873.

Kosikowski, F. V., A. R. Masters, and V. V. Mistry. 1985. Cheddar cheese from retentate-supplemented whole milk. J. Dairy Sci. 68:548-554.

Kosikowski, F. V., and V. V. Mistry. 1997a. Cheese and Fermented Milk Foods. Vol. I. Origins and Principles. F. V. Kosikowski and Associates, Westport, CT.

Kosikowski, F. V., and V. V. Mistry. 1997b. Cheese and Fermented Milk Foods. Vol. II. Procedures and Analysis. F. V. Kosikowski and Associates, Westport, CT.

Lawrence, R. C. 1987. The use of ultrafiltration technology in cheesemaking. IDF Document B 136. International Dairy Federation, Brussels, Belgium.

Metzger, L. E., and L. Leman. 2001. Measurement of temperature dependent changes in Process cheese viscosity. J. Dairy Sci. 84(Suppl. 1):257. (Abstr.)

Metzger, L. E., and V. V. Mistry. 1994. A new approach using homogenization of cream in the manufacture of reduced fat Cheddar cheese. 2. Microstructure, fat globule distribution, and free oil. J. Dairy Sci. 78:1883-1895.

Oommen, B. S., V. V. Mistry, and M. G. Nair. 2000. Effect of homogenization of cream on composition, yield, and functionality of Cheddar cheese made from milk supplemented with ultrafiltered milk. Lait 80:77-91.

SAS Institute. 1995. SAS User's Guide. Statistics, Version 6.12 Edition. SAS Inst., Inc., Cary, NC.

Shimp, L. A. 1985. Process cheese principles. Food Technol. 39:63-69.

Sood, V. K., and F. V. Kosikowski. 1979. Process Cheddar cheese from plain and enzyme treated retentates. J. Dairy Sci. 62:1713-1718.

Thomas, M. A. 1970. Use of calcium co-precipitates in processed cheese. Aust. J. Dairy Technol. 25:23-26.

Tunick, M. H. 1994. Effects of homogenization and proteolysis on free oil in Mozzarella cheese. J. Dairy Sci. 77:2487-2493.

van Vliet, T. 1990. Terminology to be used in cheese rheology. Pages 5-15 in Rheological and Fracture Properties of Cheese, IDF Bulletin No. 268. International Dairy Federation, Brussels, Belgium.

Zehren, V. L., and D. D. Nusbaum. 1992. Process Cheese. Cheese Reporter Publ. Co., Inc., Madison, WI. 